\title{
Arbeidsetiek: 'n teologies-etiese benadering
}

\author{
J.H. van Wyk \\ Dept. Dogmatologie \& Ekklesiologie \\ Potchefstroomse Universiteit vir CHO \\ POTCHEFSTROOM
}

\begin{abstract}
Work ethics - a theological-ethical perspective

The purpose of this article is to reflect on basic perspectives underlying work ethics, on the one hand, and on the other to highlight some of the most burning questions in work ethics. This is done from a Christian viewpoint, although attention is paid to Hellenistic and Marxistm approaches. It is argued that a creational as well as a pneumatological approach is onesided and that $a$ trinitarian/eschatological structure is more rewarding.
\end{abstract}

\section{Vraagstelling}

Die vraag kan met reg gestel word of daar nie al soveel oor arbeidsetiek besin is dat dit byna onmoontlik is om nog iets nuuts daaroor te sê en sodoende 'n bydrae te lewer nie. Aan die ander kant is dit ook waar dat 'n telkens verskuiwende arbeidskonteks nuwe vrae aan die arbeidsetiek stel en dus nuwe besinning as't ware vanself oproep. Die arbeidsetos van 'n agrariese samelewing sien daar anders uit as dié van 'n samelewing wat gekenmerk word deur industriële en tegnologiese rewolusies en deur outomatisasie en sekularisasie. Cox (1966:190214) vestig byvoorbeeld die aandag daarop dat die moderne stad ' $n$ aantal fundamentele veranderinge teweeggebring het, naamlik 'n skeiding van werk en woning, werk en werkgewer, werk en religie. Hierby kan gevoeg word die (fatale) skeiding tussen hande- en breinwerk.

Die Suid-Afrikaanse arbeidskonteks roep natuurlik sy eie vrae op. Dit soek antwoorde op vrae wat deur 'n sisteem van strukturele onreg (apartheid) opgeroep word, antwoorde dus op sake soos regstellende aksie, loonstakings, werkloosheid, werkskuheid, onwettige immigrante-arbeiders. En dit alles binne die konteks van 'n bevolkingsontploffing wat die arbeidsetos fundamenteel beïnvloed.

Drie voorafopmerkings moet egter gemaak word. Eerstens: onder arbeid word daardie menslike aktiwiteit verstaan wat op lewensonderhoud ingestel is, maar dan só dat dit diens aan God en die naaste asook selfontplooiing en natuur- 
beheersing insluit. 1 Arbeid moet dus van vryetydswerk en vakansiewerk onderskei word, hoewel dit nie daarvan losgemaak kan word nie.

Tweedens: onder 'n teologies-etiese benadering tot arbeid verstaan ons daardie benadering waar die Heilige Skrif as uitgangspunt, fundering en norm van besinning en praktyk geneem word. Uiteraard veronderstel dit dat die Bybel op verantwoorde wyse en nie op fundamentalistiese wyse gehanteer sal word nie (vgl. Volf, 1991:76-79). Ons stel ons nie op die standpunt van 'n kritisistiese Skrifhantering nie - vergelyk die kritiese benadering van Agrell (1976:2) wat Bienert (1954) sy kritiek- en kontekslose omgang met die Skrifgegewens verwyt. Voortdurend moet verreken word dat Jesus Christus die middelpunt en hoogtepunt van God se openbaring aan die mens is (Heb. 1:1-2) en dat ons nie buite Christus (en die Heilige Gees, Hand. 15:28) om met die Skrif mag omgaan nie. 'n Skriftuurlike besinning oor arbeid veronderstel dus onder meer 'n besinning vanuit die lewe en werk van Jesus Christus (Douma, 1985:52; Heyns, 1986:254).

Derdens: daar sal van verantwoorde situasie- en kontekstuele etiek gebruik gemaak word en wel só dat die Skrif in die konteks ingaan, maar nie daarin opgaan nie. 'n Deeglike kennis van die arbeidsetos (wat is) is vir die arbeidsetiek (wat behoort te wees) van bepalende betekenis.

\section{Navorsing}

Afgesien van werke oor die arbeidsetiek van die Vroee Kerk, het verskeie boeke in verskillende tale oor spesifiek arbeidsetiek die lig gesien. 2 Daar bestaan haas geen etiek-handboek nie of daar is uitgebreide aandag aan arbeid bestee. ${ }^{3}$

Ook in Suid-Afrika is uitvoerig oor arbeidsetiek besin en is nie minder nie as drie proefskrifte aan hierdie tema gewy: Duvenage (1957), Norval (1966; vgl. 1966a) en Faasen (1985). En dan is nog nie alles vermeld nie: vergelyk ook Heyns

1 Vergelyk byvoorbeeld Wurth (1951:232-235), Douma (1985:41), Heyns (1986:250), Bertram (1964:635-655) en Volf (1991:10-11)

2 Enkele van die belangrikste werke oor arbeidsetick is onder andere Bienert (1954), Ruchardson (1963), Van Andel (1965), Roscam Abbing (1978), Moltmann (1979), Illanes (1982), Achterhuis (1984), Ryken (1987), Mulders (1991) en Volf (1991). Dic studie van G.H. Grenholm (1993 Protestant Work Ethics A Study of Work Ethical Theories in Contemporany Protestant Theology. Stockholm Alnquist \& Wiksell International) is ongelukkig nie in Suid-Afrika beskikbaar nie

3 Vergelyk byvoorbeeld Brunner (1937:369-425), Wurth (1951:232-289), Soc (1965:229237), Thielicke (1965:395-520), Barth (1969:538-648), Trillhaas (1970:387-409), Dautzenberg (1978:343-362), Henry (1980:31-71), Rendtorff (1981:26-31, 46-49), Douma (1985:41-71) 
(1986:250-277), Van Wyk (1988) en Cochrane en West (1991). Ook in talle tydskrifartikels en brosjures is oor arbeid gehandel. ${ }^{4}$ Haselbarth (1989:130-154) het ' $n$ arbeidsetos binne Afrikakonteks probeer ontwikkel

Die aktualiteit van die tema is sonder meer duidelik. 'n Verantwoorde arbeidsetos roep egter in elke tydsgewrig om kontekstualisering en konkretisering indien dit nie waardeloos wil wees nie. Daarvoor is bepaalde boustene nodig. Hierdie boustene word gevind deur 'n noukeurige navorsing van die Ou- en NuweTestamentiese gegewens. Wat die Ou-Testamentiese arbeidsetiek betref, is baie materiaal na vore gebring. 5 Wat die Nuwe Testament betref, kan daar, afgesien van die werk van Preisker (1936), ook verwys word na die studies van ander teoloè 6

Ten einde meer relief aan ons besinning te verleen, word kortliks aandag bestee aan drie visies op arbeid - daar is natuurlik veel meeer (vgl. Achterhuis, 1984:4091; Dekker \& Veenhof, 1986; Ryken, 1987:62-77; Mulders, 1991:51 e.v.)

\section{Persepsies}

\subsection{Arbeid as slawewerk: Hellenistiese arbeidsetiek}

Onderwaardering van arbeid - in elk geval hande-arbeid - is 'n wydverspreide verskynsel wat reeds by die sogenaamde primitiewe kulture, met sy geslote stamkultuur en mitologie en aksent op kontemplasie, terug te vind is (Duvenage, 1983:1).

Hierdie tendens tree veral in die Grieks-Romeinse denk- en leefwêreld sterk na vore. Volgens Homeros is "werk die mees benouende onheil wat Zeus op die mens afgedwing het van sy geboorte af" (Du Rand, 1992:157). Die Griekse god van Plato en Aristoteles was 'n denker en nie 'n werker nie en daarom was denke vir die Grieke belangriker as hande-arbeid. Daarteenoor is die God van die Bybel 'n werker (Joh. 5:17) en die mens moet Hom in sy arbeid afbeeld (Henry, 1980:49-51). Die Grieke het in die samelewing onderskei tussen 'n bo-klas, wat hulle met kultuur besig gehou het, en 'n onderklas, meestal slawe (en vrouens), wat die (hande-)arbeid verrig het (Heyns, 1986416). Terwyl die Grieke 'n woord vir vrye tyd gehad het, naamlik scholè (waarvan ons woord skool afgelei

4 Kyk byvoorbeeld Stoker (1971-1973), Duvenage (1983), Van Wyk (1983:72-86), Vos (1986:1-12), Antonides (1989), Peterson (1990:179-188), Marshall (1991), Du Rand (1992:157-164), Orsmond (1993:128-134) en Kritzinger (1994:35-46)

5 Kyk onder andere Bienert (1954:19-129), Agrell (1976:7-32), Zimmerli (1979:40-58), Faasen (1985:90-123), Wittenberg (1991:91-108) en Mulders (1991:21-42).

6 Byvoorbecld Bienert (1954:187-387), Agrell (1976:68-149), Faasen (1985:123-174), Mulders (1991 43-50) en Orsmond (1993:128-134). 
is), het hulle geen woord vir werk gehad nie: werk was nie-vry-wees-nie (ascolia) (Marshall, 1991:3).

In die Vroeë Kerk en Middeleeue is hierdie onderwaardering van (hande-)arbeid in gewysigde vorm voortgesit. So onderskei Augustinus tussen "aktiewe lewe" (vita activa), wat alle arbeid insluit, en "kontemplatiewe lewe" (vita contemplativa), wat gerig is op meditasie oor God. Ofskoon albei goed is, is laasgenoemde tog beter (Marshall, 1991:3). Ook by Thomas Aquinas vind ons hierdie onderskeiding terug. Weliswaar voorsien hande-arbeid in lewensonderhoud, voorkom dit ledigheid, beperk dit liggaamlike begeertes en voorsien dit aalmoese (Aquinas, 1989:463); tog is dit alles gerig op die tydelike dinge. Die kontemplatiewe lewe is egter op die ewige dinge gerig en dus veel beter. 'n Lewe van kontemplasie bring meer geluk as 'n lewe van aktiwiteit (Aquinas, 1989:176, 465). Die mooiklinkende slagspreuk van ora el labora moet ook teen sy klooster-agtergrond verstaan word waar werk 'n vorm van askese was en dus ondergeskik aan die vita contemplativa (Volf, 1991:210). Die werk van monnike (vocatio) is dus belangriker as gewone werk (officium) (Heyns, 1986:252) - 'n onderskeiding wat in die nuwere Rooms-Katolieke moraalteologie nie meer gehandhaaf word nie (vgl. Neuner \& Dupius, 1983:654-657).

Dieselfde tendens openbaar hom ook in die piëtisme (Søe, 1965:233-234), terwyl bepaalde nuanses van die Charismatiese Beweging ook nie daarvan vry te spreek is nie.

\subsection{Arbeid as relfrealisering: Marxistiese arbeidsetiek}

Teenoor die Hellenisme met sy onderskatting van arbeid, staan die Marxisme met sy totale oorskatting van arbeid. Die konsep van arbeid speel in die Marxisme so 'n dominante rol dat dit veelvoudige besinning opgeroep het. ${ }^{7}$ Veral Volf het met indringende kritiek (1988:99-182) hieraan uitgebreide aandag bestee (1988:2096).

Volgens die Marxistiese arbeidsetiek kan alles wat in die menslike lewe waardevol is aan arbeid toegeskryf word. Deur arbeid word die mens méns en steeds meer mens. Arbeid maak van 'n dier 'n mens. Die ganse wêreldgeskiedenis kan omskryf word as die skepping van die mens deur menslike arbeid en die ontwikkeling van die natuur ter wille van die mens. Meer nog, die mens skép nie net homself deur te werk nie, maar hy verlos homself ook; so verseker arbeid nie net selfrealisering nie, maar ook selfverlossing. Werk ontvang 'n

7 Vgl. Kraan (1953:61-65, 341-343), Thiclicke (1965:472-485), Norval (1966:253-297), Lochmann (1976:43-50), Verkuyl (1982:164-173), Achterhuis (1984:92-110), Douma (1985:50-51), Faasen (1985:27-30, 39) Marshall (1991 6-7), Volf (1991:55-65), Mulders (1991:81-92), Manenschijn (1993:110 e.v.). 
saligmakende karakter. Arbeid maak God oorbodig. Arbeid word dus gesien as die sleutel tot die geskiedenis, tot 'n nuwe samelewing en tot 'n nuwe mens deur arbeid sal die mens vryheid verwerf en homself verlos.

Volgens die Marxisme is arbeid in die kapitalisme in vier opsigte vervreemd: eerstens is die arbeiders vervreem van hulle arbeidsproduk, tweedens van hulle arbeidersaktiwiteit, derdens van die menslike soort en vierdens van mekaar as mede-arbeiders. Die arbeider is nie meer mens nie, maar 'n ding. Privaatbesit van produksiemiddele is die eintlike bron van die vervreemding en gevolglik is die opheffing van vervreemding geleë in die opheffing van die privaatbesit van alle produksiemiddele.

By die waardevolle aksente wat die Marxistiese arbeidsetiek enersyds blootgelê het, is daar andersyds tereg kritiek uitgespreek teen die apoteose (vergoddeliking) van arbeid en teen arbeidsfanatisme (Kraan, 1953:341-343) asook teen arbeid as heilsweg. ${ }^{8}$ Ook die utopisme van die Marxisme is onaanvaarbaar (Koning, 1986:62-63).

Arbeidsoorskatting vind egter nie net in die Marxisme plaas nie, maar maak sy verskyning ook in bepaalde nuanses van die Social Gospel en Bevrydingsteologie waar die menslike arbeidsprestasie geïdentifiseer word met 'n realisering van die koninkryk van God op aarde (vgl. Moltmann, 1979:68; Antonides, 1989:3-4). Soms word ook Calviniste van arbeidsbesetenheid, werkwoede en werkolisme beskuldig (Rothuizen, 1980:46). Werkolisme is egter afgodediens wat as sodanig afgekeur moet word (Thielicke, 1965:494; Heyns, 1986:264). Die mens arbei om te lewe en hy lewe nie (net) om te arbei nie. Die mens is méér as arbeider en ofskoon arbeid nie onderwaardeer mag word nie, mag dit ook nie verabsoluteer word nie (Heyns, 1986:259).

\subsection{Arbeid as godsdiens: Christelike arbeidsetiek}

In 'n Christelike benadering tot arbeidsetiek word daarna gestreef om sowel die gevaar van onderwaardering as dié van oorwaardering te vermy. In hierdie verband speel die Christelike Godsbeskouing (Norval, 1966:60-61) en mensbeskouing (Norval, 1966:59-60) 'n deurslaggewende rol. Binne hierdie konteks word arbeid gesien as diens van die mens aan God en sy koninkryk. Arbeid is dan nie meer benede-menslik nie, dit neem ook nie afgodiese vorme aan nie, maar dit word gesien as roeping van God in diens aan sy koninkryk. In 'n Christelike

8 Lochmann (1976:68), Heyns (1986:264), Norval (1966:268-297), Chenu (1963:41-44), Verkuyl (1982:164-173) 
etiek van arbeid word gevolglik besondere aandag aan die volgende bestee: roeping, diens, sin, doel, rentmeesterskap, voldoening. ${ }^{9}$

Natuurlik bestaan daar nie so-iets as dié Christelike arbeidsetiek nie - al sou waarskynlik sonder teenspraak gestel kan word dat roeping en diens universeelChristelike begrippe is. Daarvoor varieer die Christelike perspektiewe op arbeid te veel.

In die Calvinistiese arbeidsetiek staan die roepingsgedagte (vocatio Dei) sentraal. 10 Met sy onderskeiding van roeping (vocatio) tot saligheid en beroepe (vocationes) tot diens het Calvyn na die Skrifgetuienis teruggegryp en het hy probeer om die Middeleeuse dualistiese denke van 'n hoër-laer denkskema te deurbreek. 11

Waar Thielicke (1965:395-520) sy arbeidsetiek binne die raamwerk van die Noagitiese verbond $(1965: 413,461)$ en vanuit die regverdigingsleer $(1965: 414$, 452) ontwikkel - vergelyk ook Trillhaas (1970:393) - bied Barth (1969:538-648) 'n ekklesiologiese en koninkryksbegronding aan arbeid. Die grondvorm van godsdiens (en werk) is die mens se direkte en indirekte medewerking in die Christelike gemeente (wat in diens staan van die koninkryk van God) (Barth, 1969:554-592). Die mens se medewerking aan die diens van die Christelike gemeente is sy eintlike, wesentlike, hoogste vorm van besigwees (Barth, 1969:590-591). Die Christen verrig geen kultuurarbeid nie, maar hy verkondig (net) die koninkryk van God (Barth, 1969:557-558). Ook Van Andel (1965:68, 71) interpreteer arbeid vanuit die Christologie en versoeningsleer en nie vanuit die skeppingsorde nie.

'n Volkome nuwe benadering is in die jongste tyd deur Volf $(1987$; 1991) ontwikkel, naamlik 'n charismatiese of pneumatologiese arbeidsetiek (teenoor die vokasionele (of roepings-) etiek van Luther en Calvyn), waar alle gawes wat die Gees skenk, aangewend word tot diens van die medemens, samelewing en komende koninkryk. Volgens Volf (1987:413-419; 1991:101-102, 105-110) is die Lutherse roepingsetiek te staties (dit gaan uit van 'n statiese maatskappybeskrywing) en daarom kan dit nie die moderne mobiele arbeidsituasie hanteer nie; dit lei tot ideologiese misbruik (Althaus); dit is teologies onvoldoende (omdat profetiese kritiek ten opsigte van die arbeidsituasie ontbreek); dit werk

9 Vergelyk Illanes (1982:85-93), Moltmann (1979:59-83), Ryken (1987:119-156), Mulders (1991:267-293).

10 Vergelyk Aalders (1943), Kolfhaus (1949:235-245), Wallace (1961:123-140), Faasen (1985:50-55), Ryken (1987:92-100), Van Wyk (1988:19-24), Mulders (1991:66-68)

11 Vergelyk Duvenage (1957:70-78), Velema (1980:2), Douma (1985:54), Douma (1992:107-117). 
polariserend en dit hanteer nie die probleem van werkloosheid nie. Volf (1987: $419-430 ; 1991: 111-119)$ spel ook uit wat hy verstaan onder 'n pneumatologiese arbeidsetiek, waarin hy heelwat van die tradisionele perspektiewe opneem, maar dan geplaas binne die konteks van die Pneumatologie (vgl. ook Du Rand, 1992:160-161). Hy oordeel dat die gawes van die Gees nie ekklesiologies vereng mag word nie, omdat die Gees deur die gemeente in die wêreld werk (Volf, 1987:421). Die vraag is net of Volf reg laat geskied aan die Nuwe-Testamentiese beskouing oor die charismata en of hy 'n etiek van die eskatologie nie te veel uitspeel teen 'n etiek van die protologie nie. Is 'n trinitariese benadering nie vtugbaarder as 'n unitariese benadering nie? Nietemin open Volf se koninkryksentriese benadering tot arbeid belangrike en stimulerende perspektiewe.

In Suid-Afrika is onlangs aandag gevra vir 'n arbeidsetiek vanuit die standpunt van die werker (vgl. Cochrane \& West, 1991). Die Skrif moet dan vanuit 'n werker-oogpunt gelees word (Nolan, 1991:162; Cochrane, 1991:182, 184). Eintlik moet die (nuwe) werkerservaring oor die (ou) Skrifopenbaring domineer (Cochrane, 1991:183-184); die kontekstuele teologie moet bou op die kontekstuele fenomenologie van werk (Cochrane, 1991:186). Inderdaad behoort die etiek kontekstueel beoefen te word maar sonder om in kontekstualisme onder te gaan.

In wat volg, gaan 'n multiperspektiviese benadering gevolg word, met die koninkryk van God as dominante fokuspunt. (By Ryken [1987:119-156] is die Christologiese en pneumatologiese aspekte byvoorbeeld onderontwikkel.)

\section{Sentrale perspektiewe van 'n Christelike arbeidsetiek}

Vervolgens sal getrag word om kortliks enkele sentrale perspektiewe van 'n Christelike arbeidsetiek bloot te lê, om uiteindelik in die lig daarvan enkele probleemvrae aan die orde te stel.

\subsection{Arbeid as diens aan God: Teo-logiese perspektief}

Vanuit Christelike perspektief moet gestel word dat álles, dus ook menslike arbeid, in verband met God gesien behoort te word. Arbeid is godsdiens, diens aan God. Só besien, kan vervolgens op die volgende vyf aspekte gewys word:

* Die eerste is - en hier sien ons die verband tussen Teo-logie en antropologie die feit dat die mells geskape is na die beeld van (die werksame) God en dat hy dus iets van die werksame God in sy lewe moet weerspieèl (Gen. 1:27-28). Natuurlik rus God ook, en moet die mens ook rus (Gen. 2:2; Eks. 20:11), maar God is ook die wérkende God wat dinge skep en deur sy voorsienigheid onderhou (Gen. 1; Joh. 5:17; vgl. Bertram, 1964:637-643; Faasen, 1985:9092). God openbaar Hom as die werkende God - Hy is anders as die Griekse 
godsbeskouing - en die mens moet hierdie bestaan van God ook in sy menslike lewe reflekteer; gevolglik moet die mens se werk ook die kenmerke vertoon van die manier waarop God werk (Van Wyk, 1988:47-61). Só is hy deur God geskape - menswees is (onder andere) arbeider wees - en die mens sou sy menswees radikaal aantas indien hy hiervan sou afwyk. Luiheid, leeglê, leef van rente (op jeugdige ouderdom) en dobbelary is dus in stryd met hierdie motief.

* Tweedens moet in hierdie verband opgemerk word dat die mens deur God geroep word om te werk. Arbeid is meer as 'n plig, selfs meer as 'n opdrag (Eks. 20:9), dit is veral 'n roeping van God - 'n aspek wat so sterk in Calvyn se arbeidsetiek resoneer, en nié net by Calvyn nie; 12 daarom bestaan daar nie so iets soos minderwaardige werk nie: of iemand straatveër of staatspresident is, albei is deur God geroep om te werk. Predikantswerk (geestelike werk) is in beginsel nie belangriker as prokureurswerk (wêreldlike werk) nie, omdat God mense in albei beroepe tot diens in sy koninkryk roep (vgl. Rendtorff, 1981:47; Douma, 1985:54). Natuurlik is dit waar dat sommige arbeid meer gespesialiseer is as ander en ook groter verantwoordelikheid dra, maar in beginsel is alle werk voor God gelykwaardig (Marshall, 1991:13).

* Die derde opmerking wat hier tuishoort, is dat alle arbeid diens aan God in sy koninkryk is. Weldra sal aangevoer word dat arbeid ook die self, die naaste, die samelewing en die natuur ten goede kom, maar hier is die fokus op arbeid as gods-diens. Godsdiens is nie 'n faset van die lewe nie, godsdiens is lewe. Ons dien God immers nie net Sondae in die erediens nie, nee, ons dien Hom elke sekonde van die lewe in alles wat ons doen. "Work and worship ... are both forms of divine service" (Haselbarth, 1989:133). Ons moet álles tot eer van die Here doen (Rom. 14:8; Kor. 10:31; Kol. 3:17; 1 Pet. 4:11). Ons dien Hom in en deur ons arbeid; arbeid is godsdiens. Daar bestaan nie so iets as ongodsdienstige arbeid nie. Christelike dade besit selfs 'n missiologiese intensie (Wessler, s.j.:111): buitestanders behoort Christene se goeie dade op te merk en God daardeur te verheerlik (Matt. 5:16; vgl. 1 Pet. 2:12). Buitestanders behoort selfs vir Christus gewen te word (1 Pet. 3:1-2).

* Vierdens moet arbeid ook gesien word as menslike antwoord op die roeping van God. God vra van die mens ver-antwoord-elikheid (Van Wyk, 1991:116). Die mens moet werk, hy moet dien, hy moet sy talente verantwoordelik aanwend (vgl. Matt. 25:14-30; Luk. 19:11-27). Die mens is rentmeester (in Grieks: ekonoom) van God se werk; God is immers die absolute Eienaar van

12 Vergelyk Bertram (1964:648-650), Dautzenberg (1978:344-345), Moltmann (1979:68-72), Henry (1980:35-46), Duvenage (1981:268-296), Ryken (1987:136-152), Mulders (1991:204-218, 267-273) 
die skepping (Deut. 10:14; Ps. 24:1, 50:12; 1 Kor. 10:26). Die mens moet as verantwoordelike rentmeester op aarde arbei en hy mag vir geen oomblik optree asof alles aan hom behoort nie.

* As die mens sy arbeid só besien, naamlik as afskynsel van God se werk, as roeping, as diens, as verantwoordelike rentmeesterskap, dan kan hy ook vyfdens - die seën van die Here op sy werk as genadeloon verwag. As die Here nie sy werk seën nie, staan 'n mens tevergeefs vroeg op en gaan hy tevergeefs laat slaap (Ps. 127:1-2).

\subsection{Arbeid as lewensvoorsiening en selfontplooiing: individuele perspektief}

Dit is sonder meer uit die Skrif duidelik dat menslike arbeid op lewensonderhoud gerig is (Dautzenberg, 1978:350-352). Die Here gee aan die mens 'n opdrag om die tuin (en die wêreld) te bewerk (Gen. 2:15), maar daarmee saam mag hy ook van die vrugte eet en daarvan geniet (Gen. 2:16). Paulus skryf dat elkeen in sy eie lewensonderhoud moet voorsien (Ef. 4:28; 1 Tess. 4:11) en hy vermaan leeglêers om hulle aandag by hulle werk te bepaal en hulle eie brood te verdien ( 2 Tess. 3:12). Trouens, hy sê: "As iemand nie wil werk nie, moet hy ook nie eet nie" (2 Tess. 3:10, vgl. Spr. 19:15) - 'n uitdrukking wat selfs in die Kommunistiese Handves resoneer!

By Paulus staan hierdie perspektief egter waarskynlik binne die konteks van die verwagting dat die wederkoms baie naby is en arbeid dus oorbodig is (vgl. Bienert, 1954:367; Douma, 1985:42). 'n Lewe van blote "godsdienstige kontemplasie" en "eskatologiese abdikasie" is 'n gebrekkige lewe (Marshall, 1991:11): die mens moet waak én werk, verwag én ambag vervul. Christus moet sy navolgers nie ledig nie maar besig vind met sy wederkoms (Matt. 24:46).

Die mens moet arbei om te leef - en te geniet? Gaan dit in arbeid net oor die noodsaaklike of ook oor die vermaaklike, net oor die nodige of ook oor die genotvolle? Uit die Skrif is dit duidelik dat arbeid vir lewensonderhoud nie die genotvolle uitsluit nie (vgl. Velema, 1980:15). Dit is 'n gawe van God as die mens onder al sy arbeid nog die goeie kan geniet (Pred. 3:13, vgl. 5:17). Die mens mag egter nooit sy hoop op rykdom plaas nie, maar op God wat alles ryklik aan ons gee om te geniet (1 Tim. 6:17; vgl. Spr. 30:8). Trouens, dit is opvallend hoe krities die Nuwe Testament op talle plekke oor rykdom oordeel (GKN, 1980:92; Manenschijn, 1993:121). Sowel die arbeid self as die vrug van arbeid behoort aan die mens plesier te verskaf Arbeidsvreugde (en arbeidsvergenoegdheid) vorm deel van die Christelike lewe (Wurth, 1951:270-278, Heyns, 1986: 261-262). 
Deur sy arbeid kom die mens ook tot selfontplooiing en selfverryking en ontwikkel hy die talente wat die Here aan hom/haar geskenk het. Natuurlik moet hier teen 'n arbeidsegoïsme gewaak word waar die werk so op die self gefokus is dat God en die naaste totaal uit die gesigsveld verdwyn. Selfontplooiing is ' $n$ begrip wat nie onkrities hanteer moet word nie.

\subsection{Arbeid as naastediens: sosiale perspektief}

Arbeid is op God en die self gerig, maar ook op die naaste, inklusief die samelewing. Arbeid het 'n sosiale dimensie (vgl. Duvenage, 1957:90-95; Van Wyk, 1988:116-141; Volf, 1991:189-195). Arbeid is 'n vorm van medemenslikheid. Die mens werk nie net vir homself nie, maar ook vir sy naaste en veral vir sy arm naaste. Die beroemde uitspraak van Christus, naamlik "om te gee, maak 'n mens gelukkiger as om te ontvang" (Hand. 20:35) kom juis binne die konteks van "harde werk" (handewerk) en annsorg voor: "Deur my voorbeeld", sê Paulus, "het ek in elke opsig vir julle gewys dat ons hard moet werk sodat ons die armes kan help" (Hand. 20:34). Aan die gelowiges in Efese skryf Paulus:

As iemand ' $n$ dief is, moet hy ophou steel; hy moet deur harde werk op 'n eerbare manier self in sy lewensonderhoud voorsien; dan sal hy iets hê om vir die armes te gee (Ef. 4:28).

En hierdie armes sluit nie net gelowiges in nie, maar ook ongelowiges, al ontvang die gelowiges 'n prioriteit (Gal. 6:10). Arbeid wat net op selfverryking afgestem is, arbeid wat die (naby en verre) naaste vergeet, veral die arm naaste, is egoistiese arbeid en moreel ongeoorloof.

Arbeid bevoordeel die individuele naaste, maar ook die kollektiewe naaste, ook die samelewing en die staat. Christene betaal belasting aan die owerheid (Matt. 22:21; Rom. 13:7) en dra by tot welsynsdienste in die samelewing, alles dinge waardeur die naaste baat vind. Uit die vrug van sy arbeid dra die Christen ook blymoedig by tot onderhouding van die kerkdiens (1 Kor. 9:6, 14; 1 Tim. 5:18) en voorsien hy ook middele aan die diakens om die armes te help (1 Kor. 16:1-3; 2 Kor. 8-9). Elke Christen is verplig om sy (geestelike en materiële) gawes gewillig en met vreugde tot nut en saligheid van ander aan te wend (HK 21:55). Die vrug van die arbeid mag nie op selfsugtige wyse aangewend word nie, maar moet wyd op die akker van die samelewing gesaai word sodat die welsyn van die medemens daardeur ryklik bevorder mag word.

Wie sy hand vir sy medemens toehou, en veral vir die arm medemens, steel van die Here. Wie tydens 'n erediens weinig vir die armes gee, pleeg diefstal. "Wie hom oor 'n arm mens ontferm, gee 'n lening aan die Here ..." (Spr. 19:17; vgl. Spr. 28:27). 
Deur sy arbeid skep die mens ruimte vir sy medemens, gee hy uitdrukking aan sy naasteliefde, lewer hy 'n bydrae to sosiale geregtigheid en sodoende tot die opbou van 'n verantwoordelike samelewing

\subsection{Arbeid as natuurbeheersing en kultuurskepping: kosmologiese perspektief}

Arbeid moet nie net met die Goddelike en die menslike in verband gebring word nie, maar ook met die natuurlike: die mens bewerk imıners die natuur en omskep dit tot kultuur (vgl. Van Wyk, 1988:84-97). Ook hierin weerspieël die mens iets van God, naamlik die heerskappy van God oor die aarde (Marshall, 1991:9)

Die mens moet deur sy arbeid die natur beheers en ontplooi, maar op só ' $n$ wyse dat hy die natuur nie vervuil, vemiel of met vemietiging bedreig nie. Besoedeling van die omgewing, water en lug (osoonlaag) is moreel afkeurenswaardig en vertoon die beeld van ongeremde arbeidswoede. Indien die mens sy werkterrein vernietig, kan hy tog nie meer werk mie. Onbeheerste tegnologiese ontwikkeling is nie ' $n$ ongemengde seen nie. Terwy' enersyds gewaak word teen 'n romantisering en verafgoding van die natuur, moet andersyds kant gekies word teen 'n dominasie oor en vemieling daarvan, daar moet met ander woorde gekies word ten gunste van 'n verantwoordelike beheersing van en omgang met die natuur (vgl. Volf, 1991:141-148).

Dit is gebruiklik om in hierdie verband na die sogenaande kulmurmandaat (Gen $1: 28$ ) van die mens te verwys. Hierdie term is egter nie sonder probleme nie soos onder andere Velema (1974:45-58, 1980:18-19) en Wolterstoff (1984:140-1431 tereg aangetoon het. Die kultuurmandaat verraai immers geen verhouding tot die sonde en die werk van Christus me. Die beheersende gesigspunt van die geskiedenis is nou nie meer Genesis 1:28 nie maar Matteus 24:14, sodat alle menslike arbeid nou te staan kom in die konteks van verlossing en eskatologie (koninkryk van God) Ongetwyfeld het die mens 'n roeping on te arbei, om die potensiaal van die natuur te ontploos, maar hy doen dit nou binne die raamwerk van die komende koninkryk en met die oog op die nuwe aarde - waaroor weldra meer.

\subsection{Arbeid in die greep van die sonde: hamartologiese perspektief}

Dit is uit die Bybelse boodskap dudelik dat die sonde ook sy ruinerende invloed op 'n saak soos menslike arbeid sou ulloefen (Bertram, 1964:643-647; Faasen. 1985:187-207; Ryken, 1987:128-131). Dit is egter foutief om te oordeel dat arbeid 'n gevólg van dic sonde is. Ook vóor die sondeval is daar gearbei (Gen. 1:28) en ook op die nuwe aarde sal daar gearbei word (Op. 22:3). Die sonde het egter die karakter van menslike arbeid radikaal aangetas en daarvan 'n 
swoegende handeling in plaas van loutere vreugde gemaak; die mens sal van na die sondeval af sy arbeid slegs met swaarkry klaarkry (Gen. 3:17).

Die sonde het alle verhoudings versteur: die verhouding van die mens tot God, tot sy naaste en tot die natuur. In plaas daarvan dat die mens iets van die koninklike arbeid van God reflekteer, word die mens of 'n slaaf van sy arbeid (werkolis) óf 'n niksdoener. In plaas daarvan dat hy deur sy arbeid ook die welsyn van sy medemens bevorder, word hy uitbuiter en onderdrukker. In plaas van 'n bewerker én bewaker van die natuur (Gen. 2:15), word hy ' $n$ vernieler en vernietiger. In plaas van 'n vriend het die natuur self ook nou vir die mens tot vyand geword (Gen. 3:17, 18).

Die sonde het die karakter van arbeid aangetas en dit omskep in 'n swaar én swetende besigwees met 'n weerbarstige werklikheid. Gevolglik het arbeid te staan gekom binne die raamwerk van onafheid, gebrokenheid, verbygaandheid, verganklikheid en dood. In baie gevalle het arbeid gevaarlik geword en is 'n risikofaktor daarmee saamgegee. Slegs goeie werk kan staande bly en ewigheidsbetekenis ontvang (I Kor. 3:10-15; Op. 14:13), waarmee nié gesê is dat slegs die werk van gelowiges waardevol is nie, aangesien die Here op vrymagtige wyse ook die werk van ongelowiges in sy diens kan gebruik (vgl. Op. 21:24, 26; Heyns, 1986:253, 412).

Alhoewel die sonde alle menslike arbeid radikaal aangetas het, kom die laaste woord - gelukkig - nie aan die sonde toe nie, maar aan Jesus Christus, oorwinnaar oor die sonde, demone en dood. Daarom mag die aspek van verlossing nie in die arbeidsetiek ontbreek nie.

\subsection{Arbeid deel in die verlossing van Christus en die vernuwing van die Heilige Gees: soteriologiese perspektief}

Dit spreek vanself dat in 'n Christelike benadering tot arbeid, Christus 'n sentrale plek sal inneem (vgl. Wurth, 1951:252-259; Velema, 1980:9-10; Faasen, 1985: 207-222). Die verlossingswerk van Jesus Christus word in die Skrif in omvattende terme beskryf sodat dit véél meer insluit as net die sogenaamde "redding van 'n siel"; Christus red die volle mens, die ganse kosmos, ja, die totale skepping. Paulus skryf dat die skepping, wat aan die verydeling onderworpe en sugtende is, bevry sal word van sy verslawing aan die verganklikheid (Rom. 8:2022). Christus maak deur sy Gees die hele wêreld vry! Die mens se inspanning in diens van die Here is daarom nooit tevergeefs nie (1 Kor. 15:58).

Arbeid is nie saligmakend nie, en kan dit ook nooit wees nie, maar arbeid déél in die verlossingswerk van Christus (I Kor. 15:57) en die vernuwingswerk van sy Gees. Christus verlos mense van die mag van die sonde in hulle en om hulle (Kol. 2:15) en deur sy Gees maak Hy van hulle nuwe mense (Rom. 8, Gal. 5, 
Ef. 5) wat vanuit 'n nuwe motivering en met 'n nuwe doelstelling arbeid verrig, naamlik vanuit die verlossing en met die oog op die koms van die koninkryk. Christus herstel die beeld van God in die mens en maak hom weer 'n ware reflektor van die geregtigheid en heiligheid (Ef. 4:24), barmhartigheid en mensliewendheid van God (Luk. 6:36; Matt. 5:48). Ons arbeid kan ons nie regverdig nie (Trillhaas, 1970:393), maar vorm 'n deel van ons lewe van heiliging.

Die mens se verhouding tot Christus is bepalend vir sy verhouding tot arbeid. $\mathrm{Hy}$, die timmerman van Nasaret, moet ook in arbeidsverhoudinge nagevolg word; dit is Hy wat mense vrymaak vir liefde tot God en tot die naaste. Juis die liefde soek nie sy eie belang ( 1 Kor. 13:5) en doen die naaste geen kwaad nie (Rom. 13:10). Die liefde laat nie net nié steel nie, maar ontsluit mense vir mekaar om mekaar tot diens te wees.

Sonder om te beweer dat ons 'il vokasionele met 'n pneumatologiese arbeidsetiek moet vervang - soos Volf betoog het - mag die werk van die Gees van Christus nooit uit die oog verioor word nie (Du Rand, 1992:160-161). Die Gees maak bekwaam en skenk gawes en talente wat tot nut en saligheid van die medemens aangewend behoort te word.

Tereg is opgemerk dat hierdie gawes nie ekklesiologies vereng mag word nie (Volf, 1987:421), maar daannee mag die ekklesiologiese konteks nie genegeer word nie. Nie net het die kerk 'n besondere profetiese taak ten opsigte van arbeidsbetrekkinge nie (Van Wyk, 1988:151), maar die kerk - as liggaam van Chrisius - bied ook 'n besondere ruimte vir die realisering van koninkrykswaardes (Orsmond, 1993:133). Wanneer Filemon en Onesimus begin leef ein werk vanuit die nuwe verhouding tot Christus en sy kerk, kom hulle arbeidsverhouding ook in 'n volkome nuwe lig te staan.

\subsection{Arbeid deel in die hoop op die komende koninkryk: eskatologiese perspektief}

Die eskatologiese betekenis van die koninkryk van God vir die arbeidsetiek kan nouliks oorskat word; geen wonder ine dat talle navorsers hieraan ' $n$ besondere plek toeken 13 Die waarde van die studie van Faasen (1985) is daarin geleë dat hy 'n arbeidsetiek binne die konteks van die koninkryk ontwikkel het.

Dit is duidelik dat die mens sonder die hoop op die komende koninkryk, sonder die hoop op 'n nuwe hemel en 'n nuwe aarde, 'n wanhoopbestaan voer, ook wat

13 Vergelyk Duvenage (1957.75, 96-100). Barth (1969:544, 550, 552, 584), Dautzenberg (1978:348-349), Volf (1987:423-424). Mulders (1991:271-293), Du Rand (1992:161162), Orsmond (1993:131-132) 
sy arbeid betref. As menslike arbeid nie ewigheidsbetekenis het nie (Op. 14:13), waarvoor werk hy dan? Indien Christene net vir hiérdie lewe op Christus hoop, is hulle die bejammerenswaardigste van alle mense (1 Kor. 15:19).

Arbeid binne die konteks van die koninkryk impliseer twee dinge (vgl. Velema, 1980:9-10). Ten eerste wag die gelowige op die koms van die koninkryk, maar hy wag nie in passiwiteit nie, hy wérk in verwagting. Hy werk sodanig dat sy werk bruikbaar mag wees vir die nuwe ryk (Op. 21:24,26). Daarom behoort alle Christelike arbeid kwaliteitswerk te wees en mag 'n Christen nooit met die tweede beste tevrede te wees nie. Christene arbei met die oog op en in die rigting van die komende en volmaakte Godsryk, wat 'n ryk van vryheid, vrede, vreugde en geregtigheid sal wees (Rom. 14:17). Daar is 'n sekere verbindingslyn tussen die ou wêreld en die nuwe wêreld. "(Human work), after being purified in the eschatological transformatio mundi, will be integrated by an act of divine transformation into the new heaven and the new earth" (Volf, 1991:92).

Tweedens moet dit duidelik wees dat die cooperatio Del van die mens nooit die koninkryk kan laat realiseer nie (Barth, 1969:552-553, 596; Volf, 1991:84, 92, 99-100). Die koms van die koninkryk is nié van menslike werk afhanklik nie soos in bepaalde nuanses van die Bevrydingsteologie aangetref word - maar is in die laaste instansie 'n geskenk van God. In plaas daarvan dat die mens die koninkryk laat realiseer, is dit verder só dat die koninkryk menslike arbeid teleïseer. Anders gesê: "Niet omdat de mens zinvol handelt is er toekomst, maar omdat er toekomst is, kan er zinvol worden gehandeld" (Manenschijn, 1993:116).

Dit is waar dat menslike arbeid en tegnologiese prestasies byna 'n hemel op aarde geskep het, maar dit is ewe waar dat dieselfde prestasies ook 'n hel op aarde losgelaat het. Nog nooit tevore het die mensdom met sulke ontsaglike vraagstukke soos 'n dreigende kernoorlog, ekologiese versteuring, bevolkingsontploffing, armoede en siekte (vigs) te doen gekry nie. Die Christelike geloof hou egter vol dat God uiteindelik - deur die oordeel heen - 'n nuwe (hernude) aarde en hemel sal skep (2 Pet. 3:13). Weer eens, dit beteken nie dat alle menslike arbeid en kultuurprestasies sal verdwyn nie, maar wél dat alles deur vuur gelouter en getoets sal word (1 Kor. 3:13) (eskatologiese voorbehoud).

So staan die Christelike arbeid in die perspektief van die komende Godsryk en in die teken van hoop.

\section{Probleemareas}

In die voorafgaande bespreking is enkele van die belangrikste Bybelse perspektiewe op arbeid toegelig, maar daannee is nog nie geantwoord op die konkrete vrae wat vanuit 'n gekompliseerde samelewing gestel word nie. Dit is nodig om aan enkele aktuele vrae aandag te bestee. 


\subsection{Arbeid en beroepskeuse}

Alle (voor God geoorloofde) arbeid is gelykwaardig. Sogenaamde geestelike en akademiese werk is nie belangriker as die werk van 'n loodgieter of landbouer nie (vgl. Calvyn, Inst. 3.10.6). Daar bestaan nie so iets as minderwaardige werk nie (Duvenage, 1957:118). In elke beroep word die Christen geroep om God te dien (Douma, 1985:55; 1992:113). Dit beteken egter nie dat almal alles kan en moet doen nie. Elke mens het 'n bepaalde aanleg en talente ontvang wat hom meer geskik maak vir een soort werk as vir ' $n$ ander. Met sy beroepskeuse moet hy dan daarmee rekening hou. Binne 'n Christelike perspektief behoort die mens egter nie nét met die winsmotief - ten koste van die diensmotief - rekening te hou nie, maar sal hy ook die welsyn van sy naaste en die samelewing in berekening bring. Slegs wanneer persoonlike arbeidsgeluk en goeie beloning sinvol verbind is met die welsyn van die naaste en samelewing asook sorg vir die natuur, is daarin geslaag om 'n korrekte beroepskeuse uit te oefen.

Die vraag ontstaan of beroeps- en werkverandering mag plaasvind. Is dit nie in stryd met 1 Korintiërs 7:20-24 nie waar Paulus skryf dat elkeen in die samelewing moet bly, en God dien, in die omstandighede waarin hy was toe God hom geroep het? Nee. Uit die konteks blyk duidelik dat Paulus adviseer dat bekeerlinge nie net omdat hulle Christene geword het, hulle werk moet neerlê en 'n ander werk moet gaan doen nie - tensy daardie werk in stryd is met die evangelie. (Bevoorregting van werkers ondat hulle Christene is (of geword het) is ook immoreel.) Voorts moet opgemnerk word dat die evangelie van die koninkryk nie die samelewing op rewolusionêre wyse onverwerp nie, maar dit deursout (Matt. 5:13) en deursuur (Matt. 13:13) en van binne-uit transformeer. Op hierdie wyse is slawerny deur die evangelie van binne ondermyn (Filem. 1:16) sodat dit uiteindelik afgeskaf kon word. Indien alle Christene destyds skielik hulle werk sou moes bedank het, sou dit 'n volkome wêreldvreemde indruk geskep en die sannelewing baie benadeel het. Dit is dus nie ongeoorloof om van beroep te verander nie (vgl. 1 Kor. 7:21), hoewel dit altyd sinvol en met suiwer motiewe behoort plaas te vind (vgl. Douma, 1992:111-114).

Daar is geen minderwaardige werk nie, maar daar is wel so iets as ongeoorloofde werk of beroep. Eties is daarvoor nagenoeg eenstemmigheid. 14 Die Vroeë Kerk was byvoorbeeld sterk gekant teen bordele, prostitusie, toneelspelers en stiervegters. In latere tye het die kerk negatief geoordeel oor beroepskriminaliteit, beroepswedders, dobbelaars en bepaalde soort vermaaklikhede. Duvenage (1957:118-119) onderskei tussen ongeoorloofde en twyfelagtige beroepe en tot laasgenoemde reken hy onder andere beroepsport, boks,

14 Vergejyk Kolfhaus (1949:242) (t o.v Calnn), Wurth (1951:268), Duvenage (1957:118. 119), Suc (1965:237), Thiclicke (1965 449), Barth (1969:609). Trillhaas (1970:394), Henry (1980 44-45), Duvenage (1983 II), Douma (1985:55), Wessler (s.j. I17) 
stoei en beroepsgrapmakers. Waarskynlik moet tabakboerdery hier bygevoeg word. Waar etici aanvanklik negatief oor beroepsport geoordeel het (vgl. Duvenage, 1957:119; Heyns, 1986:261; Douna, 1992:203-207), bevind steeds meer en meer Christene hulle in hierdie "beroep" en streef hulle ook daarna om hulle Christenskap daar uit te leef. Die Christelike etiek sal hierdie nuwe stand van sake krities moet aanvaar - soos wat toneelspel krities aanvaar is - en sal die verdere ontwikkeling daarvan ook krities vanuit die evangelie moet begelei ( $\mathrm{vgl}$. Van Zijl \& Putter, 1992:129-138).

'n Christen mag nie 'n beroep kies of ' $n$ werk doen waarvan hy weet dat dit Godonterend, mensveragtend, selfvernederend of natuurskendend is nie.

\subsection{Arbeid en loon}

Die Bybel is daaroor duidelik dat die arbeider op sy loon geregtig is (Matt. 10:10; Luk. 10:7; 1 Tim. 5:18) asook dat iemand wat 'n ander se loon terughou, 'n groot oortreding begaan (Lev. 19:13; Jak. 5:4).

Die etiese vraag is egter hoe loon bepaal en watter kriteria daarvoor aangelê moet word (vgl. Verkuyl, 1982:149-162; Duvenage, 1983:11-14; Faasen, 1985:255262; Heyns, 1986:266-268). Die eerste wat hier verreken moet word, is die aard van die werk. So sal 'n vlieënier meer ontvang as die vlugpersoneel vanweë die langer voorbereiding, groter vaardigheid en swaarder verantwoordelikheid wat van hom vereis word; en so sal 'n staatspresident meer ontvang as sy sekretaris ensovoorts. 'n Tweede maatstaf wat aangelê moet word, is loon volgens arbeidsprestasie. Die loon moet die arbeider waardig wees, maar die arbeider moet ook sy loon waardig wees (vgl. Petersen, 1990:182). Wanneer iemand goed presteer en produseer, behoort hierdie prestasie in sy beloning te reflekteer. 'n Derde faktor wat verreken behoort te word, is die kwalifikasies (akademies, tegnies, ervaring) waaroor iemand beskik. Uiteraard is dit nie die énigste wat verdiskonteer moet word nie, maar ontkenning daarvan sou die werknemer in sy menswees aantas. 'n Vierde aspek is persoonsbehoefte. Die werkgewer het immers nie met ' $n$ artikel te doen nie, maar met 'n mens met menslike behoeftes (Verkuyl, 1982:153). As 'n werknemer (en sy gesin) nie 'n menswaardige bestaan kan voer nie, is die loon waarskynlik te laag. In die Suid-Afrikaanse konteks impliseer hierdie standpunt dat wit werkgewers (sakemanne, boere, huisvroue) bedagsaam moet wees om aan hulle swart werknemers menswaardige lone te betaal en om hierdie lone in die lig van die voortslepende inflasie en ekonomiese toestande voortdurend te hersien.

Die arbeider is op sy loon geregtig, het ons gesê, maar die omgekeerde is ook waar: die beloner is op arbeid geregtig. Wie halfhartig en tydverkwistend werk, pleeg diefstal teenoor sy werkgewer. Die slagspreuk van Benjamin Franklin "tyd 
is geld" is eties besien problematies, maar dit bevat tog dié waardevolle verwysing dat arbeidstyd nie verkwis nie maar benut behoort te word.

In die nuwe post-apartheid-konteks in Suid-Afrika met sy regstellende aksie rus daar ' $n$ groot verantwoordelikheid op veral swart werknemers om belangrike ekonomiese waardes soos produktiwiteit, effektiwiteit, kwaliteit, kompetensie en verantwoordelikheid hoog te hou. Afrika beskik nie oor 'n goeie werketos nie (Kinoti, 1994:24). Wanneer bogenoemde waardes verdwyn, kan die landsekonomie baie moeilik groei vertoon. Veral moet daarteen gewaak word dat die tradisionele twee-dimensionele tydsbeskouing van Afrika (verlede en hede) (vgl. Van Wyk, 1993:90; Kinoti, 1994:46-47) nie die arbeidsetos nadelig beinvloed nie. Daarvoor neem beplanning, vooruitskouing en toekoms net ' $n$ te belangrike plek in die arbeidsetos in.

Ook moet omkopery, wat 'n wydverspreide verskynsel in Afrika is (Haselbarth, 1989:135), hand en tand beveg word.

\subsection{Arbeid en diskriminasie}

Die vraag ontstaan of daar op die arbeidsmark gediskrimineer mag word. Mag aan mans meer betaal word as aan vrouens, aan wit mense meer as aan swart mense, aan gesondes meer as aan gestremdes, aan heteroseksueles meer as aan homoseksueles, aan nie-vigslyers meer as aan vigslyers (vgl. Volf, 1991:38-39)? Of behoort in alle gevalle die stelreël te geld: gelyke betaling vir gelyke werk?

Daar heers onder etici wye eenstemmigheid dat daar gelyke betaling vir gelyke werk behoort te wees, al moet hier moontlik bygevoeg word: vir gelyke werksprestasie. "Gelyke werk" veroorsaak immers nie outomaties "gelyke werkprestasie" nie, dit is immers moontlik om "gelyke werk" te doen en onder te presteer. As algemene stelreël behoort egter te geld dat diskriminasie op grond van geloof, ras, kleur, kultuur of geslag immoreel is (Heyns, 1986:265, 266). Die vorige onderwysbedeling in die RSA, waar die getroude vrou minder beloning as die man vir dieselfde werk ontvang het (soos deur sommige bepleit word: Duvenage, 1983:15), moet dus moreel afgekeur word (Heyns, 1986:276-277). Sowel man as vrou het immers in Genesis 1:28 dieselfde kultuuropdrag ontvang (Douma, 1985:56; Heyns, 1986:276). Uiteraard sal elke werkende moeder deeglik met haar gesinsomstandighede en opvoedingstaak rekening moet hou wanneer sy buitewerk aanvaar.

Eweneens moet die etiek van die apartheidsmodel met sy werksreservering en bevoordeling van blankes bo swartes moreel afgewys word. Dit is in stryd met die gebod tot naasteliefde en met die eis van geregtigheid. (Dit val op dat Duvenage [1972:364] die konsep van werkreservering aanvanklik aanvaar, maar dit later laat vaar het.) Waar gestremdes dieselfde werk as nie-gestremdes verrig, 
behoort hulle gelykberegtig te word. Ook teen homoseksuele persone en vigslyers behoort nie sonder meer gediskrimineer te word nie, aangesien ook hulle 'n arbeidstaak ontvang het.

\subsection{Arbeid en loonstaking}

Die vraag kan gestel word of loonstakings en arbeidsboikotte, veral in 'n geval van diskriminasie, uitbuiting en onreg, moreel geoorloof is en of 'n Christen daaraan mag deelneem. Het vakbonde met bedingingsmag ' $n$ morele reg van bestaan?

Wanneer oor stakings - gewoonlik gedefinieer as die tydelike opskorting van arbeid ten einde regverdige arbeidsvoorwaardes en lone te beding - besin word, moet verreken word dat daar verskillende soorte stakings is, soos byvoorbeeld ekonomiese en politieke stakings, selektiewe en kollektiewe stakings, sloer- en sitstakings, protes- en verkeerstakings.

In die Christelike etiek is daar geen beswaar teen die bestaan van vakbonde wat 'n wakende oog hou oor arbeidsverhoudinge en loonskale nie. Vakbonde behoort egter nie hulle bedingingsmag te oorspan nie, en sodoende kontra-produktief op te tree en die landsekonomie te ruineer nie. Etici oordeel gereserveerd oor ekonomiese stakings (Geesink, 1931:332), omdat die evangelie eerder met 'n harmonie- as 'n konflikmodel werk (Douma, 1985:175-178). (Ten opsigte van die politieke etiek - reg tot opstand - huiwer Douma [1984:202-203] egter nie om die konflikmodel te hanteer nie!) Tog word stakings nie volkome uitgesluit nie. Stakings is ' $n$ sosiale bedingingsmeganisme om magsmisbruik en onreg te voorkom. In die geval van 'n arbeids- en loonkonflik is die eerste keuse egter altyd die weg van oorlegpleging, onderhandeling, mediasie en arbitrasie en nié stakings en geweld nie (Wurth, 1951:281; Duvenage, 1957:153; 1983:18). (Daarom behoort daar ook in die geval van 'n loondispuut meganismes soos konsultasies, arbitrasie en rekonsiliasie te wees om sodanige dispute te hanteer.) Loonstakings kom egter wẻl ter sprake indien daar 'n hardnekkige en liefdelose kontinuering van ' $n$ onregsituasie plaasvind en nadat alle onderhandelinge gefaal het (Duvenage, 1957:153;1983:18), maar selfs dan nog moet dit met die nodige diskresie toegepas word sodat die (slegte) gevolge nie die (goeie) doel vernietig nie. Laasgenoemde impliseer dat 'n staking ordelik behoort te verloop sonder saakbeskadiging; dit behoort vry te wees van intimidasie, manipulasie en massafikasie; dit mag nie ingestel wees op ekonomiese anargie en maatskappyvernietiging nie.

Sluit stakings ten opsigte van die sogenaande non-vitale (nie-essensiële) dienste ook stakings ten opsigte van vitale (essensiele) dienste in (dokters en verpleegsters)? En wat van polisie- en onderwysdienste? Gelukkig staan die Suid-Afrikaanse wetgewing afwysend teenoor stakings ten opsigte van mediese 
dienste en polisiëring. So 'n verbod behoort egter nie 'n vrypas te wees aan burokrate en owerhede om onbillike loonskale af te dwing nie; inteendeel, juis omdat werknemers hier in vitale dienste werksaam is, behoort die loonstrukture gunstig en menswaardig te wees. Alle werkgewers behoort deur pro-aktiewe optrede loonstrukture sodanig saam te stel dat stakings nie opgeroep word nie, maar betyds voorkom kan word.

Twee slotopmerkings moet hier gemaak word. Enersyds moet vakbonde sorg dra dat hulle genoegsame kontrole oor stakende lede kan uitoefen, sodat (onwettige) stakings teen die wil van vakbonde in (soos die verpleegsterstakings van 1995) uitgeskakel kan word. Andersyds moet vakbonde, wanneer hulle 'n staking geïnstigeer maar dit misluk het, die (mede-)verantwoordelikheid van die mislukking en eventuele afdankings en sluitings aanvaar.

\subsection{Arbeid en werkloosheid}

Die vraagstuk van werkloosheid is al beskryf as vall die moeilikste en gekompliseerdste vrae van die ekonomie (Brunner, 1939.629, Van Wyk, 1988136) en gevolglik is dit al aan indringende navorsing onderwerp (Roscam Abbing, 1978:57-112; Faasen, 1985:325-340, Nümberger, 1991:28-65). Wat is die oorsake van werkloosheid en watter gevolge bring dit mee vir menswees? Is werk 'n rég, en indien wel, wie moet hierdie reg waarborg in 'n situasie van werkloosheid?

Die bewering word gemaak dat daar tans in Suid-Afrika (met sy ongeveer 40 miljoen inwoners) ten minste drie miljoen werklose mense is - en sommige stel die syfer so hoog as agt miljoen. Werkloosheid hang saan met 'n wye reeks faktore soos ekonomiese insinking, inflasie, natuurrampe, werkskuheid, werksnalatigheid, siekte, bevolkingsgroei asook 'n ekonomiese sisteem. $\mathrm{Al}$ is werk 'n opdrag, en moontlik ook 'n reg (vgl. Thielicke, 1965:415-420; Brakelmann, 1979:9-39; Douma, 1985:66-69, Robertson, 1991:157-163), is werkloosheid nogtans 'n wêreldwye verskynsel en 'n skynbaar onoplosbare vraagstuk. Wat egter belangrik is, is dat 'n werklose mens nooit in sy werklose situasie moet berus nie, maar moet oorweeg om eerder laagbesoldigde en selfs onbetaalde werk (bv. welsynswerk) te doen ten einde aan sy Goddelike roeping uitvoering te gee (Douma, 1985:71). Gesien die wyse waarop iemand se totale menswees deur werkloosheid aangetas w'ord, moet 'n situasie van niksdoen ten alle koste verny word. Daarby behoon sakeondememings uiters omsigtig met afdankings om te gaan en behoort daar eerder korter werkstye met 'n kleiner salaris ingestel te word as ' $n$ personeelvennindering. Laasgenoemde bring ook dikwels oortydwerk en werksoorlading mee, met al die persoonlike en gesinsnadele daaraan verbonde. 
Soms word die oorsaak van werkloosheid aan "die sisteem" (politiek en/of ekonomies) toegeskryf. Vanuit die Marxisme is die kapitalisme gekritiseer, maar sedert die ineenstorting van die sosialistiese sisteme vanaf 1990 het hierdie kritiek veel geloofwaardigheid verloor - hoewel Slovo (1995:77) volhou dat die misbruik van sosialisme die goeie gebruik daarvan nie ophef nie (soos in die geval van die Christendom). Die val van sosialisme impliseer egter nie dat die vryemarkekonomie kritiekloos aanvaar moet word nie (Duvenage, 1983:22-25). Dit getuig egter van volslae ooroptimisme on te dink dat as "die sisteem" (van apartheid) eenmaal verander (het), daar werk vir almal sal wees (Taki, 1991:173). Die Christelike etiek behoort volgehoue en indringend ondersoek in te stel na daardie ekonomiese sisteem wat die meeste reg laat geskied aan regverdigheid en vryheid - en aan menswaardigheid. Hierdie ondersoek impliseer 'n kritiese evaluering van kapitalisme en sosialisme, sosiale demokrasie en demokratiese sosialisme (vgl. Leat et al., 1986; Manenschijn, 1987; Nyirongo, 1994). Waarskynlik moet die oplossing in die rigting van een of ander gemengde sisteem gesoek word (vgl. Van Wyk, 1986:171-185).

Dit is egter duidelik dat indien die bevolkingsgroei nie beheer kan word nie, geen program of sisteem die werkloosheidsprobleem voldoende sal kan oplos nie (Kinoti, 1994:61-64).

\subsection{Arbeid en regstellende aksie}

Regstellende aksie het veral in die Suid-Afrikaanse konteks aktueel geword vanwee die apartheidsbeleid waardeur oor vier dekades teen swart mense op die arbeidsmark gediskrimineer is en hulle aan 'n sisteem van trekarbeid blootgestel was (Faasen, 1985:357-376; Heyns, 1986:265-266). Heelwat besinning het reeds hieroor plaasgevind. 15

Onder regstellende aksie word gewoonlik verstaan dat verontregte gemeenskappe van owerheidsweè af geliberaliseer en gekompenseer behoort te word. Dit gaan dus oor distributiewe maar veral kompenserende geregtigheid.

Die saak self is natuurlik nie sonder vrae nie. Om enkeles daarvan op te som: Sal regstellende aksie nie die konsep van meriete laat verdwyn nie? Sal dit nie produktiwiteit verlaag nie? Sal dit nie standaarde verlaag nie? Sal dit nie prestasie ondermyn nie? Sal kwalifikasies geïgnoreer moet word? Is dit nie 'n vorm van omgekeerde diskriminasie wat problematies is nie? Maak dit nie gebruik van growwe generalisasie nie. Is alle blankes skuldig (hoewel

15 Vergelyk byvoorbeeld Esterhuyse (1991:86-94), Ramos en Cassim (1991:128-148), Smit (1992:31-57), Adams (1993), Van der Merwe (1994), Charton en Van Nickerk (1994), Kruger en De Klerk (1995) Die Suid-Afrikaan van 44/1993 word gehocl aan hicrdic onderwerp gewy 
bevoordeel)? Is alle swartes onskuldig? Sal dit nie die menswaardigheid van swart mense aantas, veral waar iemand vir 'n taak nie opgewasse is nie? Is daar nie meer vergelding as vergoeding nie? Waar is die beginpunt en waar die eindpunt? Vind regstellende aksie nie al lankal plaas nie? Kan regstellende aksie ooit slaag indien groepe se arbeidsetiek verskil?

Volgens Sadie (1992:2) offer blankes reeds $32 \%$ van hulle persoonlike inkomste aan die fiskus op om herverdeling moontlik te maak. Dit beteken dat die gemiddelde blanke byna vier maande vall die jaar vir sy medemens en die staat werk - by die boonste inkomstegroepe is dit ses maande. Hierby moet dan nog vrye donasies vir welsynswerk gevoeg word. (Vanselfsprekend word daar nie van regstellende aksie binne die raamwerk van die kerk gepraat nie, maar wel van sustentasie en barmhartigheidsdiens. So gesien moet opgemerk word dat "blanke" kerke miljoene rande aan "swart" kerke bygedra het ten opsigte van Woordbediening, teologiese opleiding, armsorg en sending.)

'n Ander vraag wat - veral ten opsigte van grondverdeling - na vore kom, is die vraag hoever daar in die verlede teruggegaan behoort te word. Die swart mense van Suid-Afrika verwyt die blankes van gronddiefstal kragtens 'n polities gestruktureerde model, maar moet daar me ook, naas die wit teen swart onreg, gekyk word na die (vroee) swart teen swart onreg nie? Het die (nasate van die) Khoisan nie dalk die grootste aanspraak op die grond van Suid-Afrika nie (vgl. Cameron \& Spies, 1991)? En wat van die onreg van die Engelse teenoor die Boere (1899-1902)? Of is hierdie vraag in die Suid-Afrikaanse konteks irrelevant? "The land belong to the people" - Inaar presies watter "people"?

Die vraag dring hom vanself na vore of daar vanuit die teologiese etiek enige perspektiewe gegee kan word.

Ongetwyfeld lewer die Ou Testament belangrike rigtingwysers, waarvan die Jubeljaar (vgl. Lev. 25:10) 'n sprekende voorbeeld is (vgl. Mazamisa, 1994:211, 215; vgl. ook Deut 15). Die vyftigste jaar is 'n hersteljaar en dan moet daar ' $n$ afskrywing van skuld plaasvind, elke Israeliet moet sy grond terugkry en hy mag na sy familie terugkeer. Op hierdie wyse is sowel die opeenhoping van kapitaal as die verarming van die bevolkmg teengegaan. Sodoende is duidelik daaraan herinner dat slegs die Here God alleenbesitter is (Lev. 25:23); álles behoort aan die Here (Ps. 24:1). Die grond behoort dus aan die Here en nie aan die people nie, hoewel laasgenoemde die opdrag het om op 'n verantwoordelike en regverdige wyse daannee oin te gaan. So pas is die woord geregtigheid gebruik, 'n woord wat, meer as enigiets anders, vir die arbeidsetos van deurslaggewende betekenis is. 'n Belangrike toetsingskriterium is die vraag of daar in 'n samelewing reg aan die arme geskied (Noordegraaf, 1987:13, 23). Die onregmatige wyse waarop Isebel (en Agab) vanuit 'n magsposisie die wingerd van Nabot bekoin het (1 Kon. 2l) - en die straf van die Here hierop - lewer hiervan 'n 
lewende illustrasie (vgl. Bosman et al., 1991:22, 45-51, 58-65, 226-228). Ook in die Nuwe Testament klink iets hiervan deur wanneer Saggeus, na sy ontmoeting met Jesus, onmiddellik bereid is om vierdubbel terug te gee waar hy van iemand iets afgepers het (Luk. 19:8) (vgl. Du Toit, 1994:185-199). Só 'n benadering is begryplik as in gedagte gehou word dat die Jubeljaar in Christus aangebreek het (Luk. 4:19).

Dit spreek vanself dat hierdie gegewens in die eerste plek in 'n geloofsgemeenskap en binne 'n verbondskonteks ter sprake kom.

In Suid-Afrika, met sy dekades van strukturele en gelegitimeerde onreg, is regstellende geregtigheid moreel geoorloof en noodsaaklik, veral as in gedagte gehou word hoe belangrik grond/land vir die Afrikaan is (Boesak, 1995:63-68). Boesak (1995:202 e.v.) bepleit 'n etiek van vergelding - wat onderskei moet word van 'n etiek van wraak. Vergelding, wat vergewing natuurlik nie uitsluit nie, moet ordelik en wettig uitgevoer word. Daar kan egter geen sprake van vergewing wees sonder vergelding (en restitusie) nie. Versoening sonder vergoeding is onaanvaarbaar. Sonder twyfel het Boesak 'n uiters belangrike saak aan die orde gestel, en sy verset teen 'n goedkoop genade verdien ondersteuning. Sy uitwerk van die tema roep egter bepaalde vrae op (Van Wyk, 1995:22-23). Hoe gemaak met onreg wat uit onkunde en selfs onwil begaan is? Wat van onreg wat nooit weer reggestel kan word nie? Wat van die oproep om onbeperk (Matt. 18:21-35) en onvoorwaardelik (Ef. 4:32) te vergewe? Staan nie juis húlle wat nie bereid is om te vergewe onder die oordeel van God nie (Matt. 18:32-35)? Is die veronderstelling vir vergifnis geleê in vergoeding en vergelding of in berou en skuldbelydenis? Het God ons nie met Homself in Christus versoen toe ons nog vyande van Hom was nie (Rom. 5:10)? In elk geval moet hierdie vrae binne ekklesiologiese konteks gestel word. Die straf op die sonde (van onreg) het Christus immers gedra; Hy het die volle prys betaal. Gesamentlike Nagmaal is sonder vergifnis en versoening eenvoudig onmoontlik. Binne juridiese konteks egter, moet die onreg reggestel word en kan daar geen sprake van versoening wees sonder 'n prys en sonder geregtigheid nie (König, 1995:76). Regstellende geregtigheid is ' $n$ morele eis, maar dan gehanteer binne die raamwerk van bepaalde kriteria.

Van der Merwe (1994:23-29) ${ }^{\mathbf{1 6}}$ het hierdie kriteria soos volg saamgevat:

Regstellende aksie:

* moet nie in 'n ideologie ontaard nie;

* moet gepaard gaan met 'n (wit en swart) mentaliteitsverandering;

16 Vergelyk Smit (1992:51-56), Villa-Vicencio (1992:248-251), Kruger en De Klerk $(1995: 419-424)$ 
* moet mense nie hulle morele outonomie beroof nie;

* moet nie ten koste van meriete, kwalifikasies en standaarde deurgevoer word nie;

* moet gepaard gaan met ' $n$ opvoedings- en opleidingsprogram wat selfhelp as oplossing beklemtoon;

* moet 'n streng gekontroleerde en tydelike maatreël wees;

* moet voorkeurbehandeling beperk tot gelykgekwalifiseerde kandidate,

* moet bydra tot die vestiging van 'n gemeenskaplike waardesisteem.

Uiteraard is hierdie lys nie bedoel om volledig en finaal te wees nie - daar kan byvoorbeeld bygevoeg word dat ' $n$ verantwoorde werksetiek en geldbeskouing (die voorraad geld is nie onbeperk nie) asook produktiwitelt baie belangrike faktore is - maar dit lewer ' $n$ belangrike en genuanseerde bydrae tot die huidige diskussie oor regstellende geregtigheid.

Regstellende geregtigheid is, moreel gesien, ' $n$ moet. Dit behoor egter só toegepas te word dat die samelewing gereinig en gestimuleer en nié vernietig word nie.

\subsection{Arbeid en rus}

Arbeid is onlosmaaklik deel van menswees, maar omvat nie die volle menswees nie. Menswees is méér as arbeider wees, werk omvat nie die mens se totale bestaan nie. Werk word telkens deur ' $n$ korter of langer rusperiode onderbreek (vgl. Faasen, 1985:224-241; Heyns, 1986:272-276; Van Wyk, 1988:145-147). Die etiek van arbeid moet met die etiek van rus gekomplementeer word. Ook in hierdie opsig weerspieèl die mens iets van God wat werk én rus. So werk die mens nie 24 uur nie, maar net bedags terwyl hy (die meeste mense altans) snags rus; hy werk nie sewe dae van die week nie, maar net ses (of vyf) en rus een dag; hy werk nie twaalf maande van die jaar nie, maar net elf; hy werk selfs nie sy lewe lank nie, maar voer na aftrede 'n meer rustige - hoewel nie werklose bestaan. Natuurlik is daar mense wat hierdie ritme verbreek en hulle lewe meer op rus, weg-naweke en vakansie as op werk instel. So 'n benadering is ongetwyfeld afkeurenswaardig, aangesien dit sowel rus as arbeid sy ware karakter ontneem.

Die etiek van vryetydsbesteding behoort sy regmatige plek in die sosiale etiek in te neem (Faasen, 1985:342-355; Heyns, 1986:391-448; Heintzman et al., 1994). Afgesien van werkstyd (Maandag tot Vrydag) en rustyd (Sondag) is daar ook vrye tyd (Saterdag) wat sinvol gevul moet word deur byvoorbeeld spel of sport, lees, sosiale dienste of 'n stokperdjie 
Teologies gesien, is Sondag by uitstek die rusdag, die dag van verademing (Eks. 20:9-11). Op die Sondag kom die mens tot stilstand, vergader hy in die erediens en word hy opnuut herinner aan die verlossende werk van Christus en die vernuwende werk van die Heilige Gees; opnuut dus word hy herinner dat die koms van die koninkryk nie van sy werk afhanklik is nie, maar van God. So vind die mens alleen rus in Gód (Barth, 1969:644-648). Die prestasie-moraal van die week word ondraaglik sonder die ekstase en entase (inkering) van die Sundag.

Die Sondagrus is in 'n moderne samelewing egter grootliks versteur deur verskynsels soos Sondagarbeid en Sondagsport. Die Christelike etiek het nog altyd ruimte gelaat vir noodsaaklike Sondagarbeid (Douma, 1986:64; Heyns, 1986:276) maar die vrae rondom Sondagsport is nog nie naastenby bevredigend beantwoord nie (vgl. Van Wyk, 1986:54-60). Dit skyn asof die gangbare onderskeiding tussen (geoorloofde) spontane spel en (ongeoorloofde) georganiseerde sport nie meer deug nie; trouens, daar is miljoene Christene wat gewetensvry aan Sondagsport deelneem, meer nog, wat dit ook as geleentheid sien om hulle Christenskap uit te leef. In Suid-Afrika is dit lankal praktyk dat swart gereformeerde Christene - veral vanweè die arbeidsopset en politieke sisteem soggens 'n erediens bywoon en Sondagmiddae aan sport deelneem. Die groot vraag wat hier ondersoek en beantwoord moet word, is of die tradisionele Gereformeerde Sondagetiek nie méér met 'n puriteinse as met 'n Christelike inkleding te doen het nie. Waarom was Sondagarbeid in die eerste drie eeue van die kerkgeskiedenis nie 'n sensurabele oortreding nie? Waarom bevat die Nuwe Testament geen direkte opdrag om die vierde gebod te onderhou nie (Douma, 1986:11)? Wat is die korrekte eksegese van Romeine 14:5; Galasiërs 4:10-11 en Kolossense 2:16-17?

'n Sondag sonder erediens en sonder opstandingsfees is egter vanuit Christelike perspektief ondenkbaar. Vandaar dat 'n Christelike Sondagetiek veral hiérop moet konsentreer eerder as om 'n lysie te probeer saamstel oor dinge wat alles op 'n Sondag nagelaat behoort te word.

\section{Konklusie}

Die mens is arbeider, en deur sy arbeid dien hy God, maar die mens is ook méér as arbeider. Hy is - Christelik besien - kind van God, ja, verloste kind van God, wat werk nié om verlos te word nie, maar omdat hy verlos is; wat dien nié om in God se goeie boekies te wees nie, maar omdat sy naam in die Boek van die Lewe staan; wat arbei nié om die Godsryk in eie krag te laat realiseer nie, maar omdat God die voltooiing van sy ryk belowe het.

Arbeid is godsdiens, maar dit is ook naastediens, gemeenskapsdiens en natuursorg. Daarmee bly die mens besig tot hy die finale uitspraak hoor: "Mooi 
so! Jy is ' $n$ goeie en getroue slaaf. Oor min was jy getrou, oor baie sal ek jou aanstel. Kom in en deel in my vreugde!" (Matt. 25:21-23).

\section{Bibliografie}

AALDERS, W J. 1943. Roeping en beroep bij Calvijn. Amsterdam : Noord-Hollandsche Uitgever

ACHTERHUIS, H 1984. Arbeid, een eigenaardig medicijn Baarn : Ambo

ADAMS, C. 1993. Affirmative action in a democratic South Africa. Kenwyn : Juta.

AGRELL, G. 1976. Work, toil and sustenance Verbum : Hakan Ohlssons.

ANTONIDES, H. 1989. A Christian perspective on work and labour relations. Potchefstroom : IRS/PUCHE.

AQUINAS, ST THOMAS. 1989. Summa Theologiae: A concise translation London : Eyre and Spottiswoode. (Transl. by $T$ McDermott.)

BARTH, K 1969. Die Kirchliche Dogmatik 1114 Zurich : EVZ-Verlag.

BERTRAM 1964. Epyovv. (In Kittel, G, ed Theological Dictionary of the New Testament. Grand Rapids . Eerdmans p. 635-655.)

BIENERT, W. 1954 . Die Arbeit nacht der Lehre der Bibel: Ein Beitrag zur evangelischer Verlag. Stuttgart : Evangelisches Verlagswerk.

BOESAK, W 1995. God's wrathful children: Political oppression and Christian ethics. Grand Rapids : Eerdmans.

BRAKELMANN, G 1979. Das Recht auf Arbeit. (In Moltmann, J. Hrsg Recht auf Arbeit, Sinn der Arbeit. München : Kaiser. p. 9-39.)

BOSMAN, H.L., CROUS, I.G P \& SPANGENBERG, I.J.J., reds 1991. Purper en flenterlap: Rykdom en armoede in die Ou Testament. Pretoria Van Schaik.

BRUNNER, D.E. 1939. Das Gebot und die Ordnungen: Entwerf einen protestantischtheologischen Ethik. Zürich : Zwingli-Verlag

CALVYN, J 1984/1986/1988/1992. Institusie van die Christelike Godsdiens 1-4 Potchefstroom : CJBF (Ver. H.W. Simpson.)

CAMERON, T \& SPIES, S B., red. 1991. Nuwe geskiedenis van Suid-Afrika. Kaapstad Human en Rousseau.

CHARLTON, G \& VAN NIEKERK, N.L, ed. 1994. Affirming action beyond 1994 Kaapstad : Juta.

CHENU, M.D. 1963. The theology of work : An exploration. Dublin : Gill \& Son

COCHRANE, JR. 1991. Already ... but not yet: Programmatic notes for a theology of work (In Cochrane, J R \& West, G.O, ed. 1991. The three-fold cord: Theology, work and labour. Hilton: Cluster. p 177-189.)

COCHRANE, JR \& WEST, G.O, ed. 1991 The three-fold cord Theology, work and labour. Hilton : Cluster

COX, H. 1966. De stad van de mens Het lewenspatroon van de geseculariseerde wêreld in theologisch perspectief Utrecht: Ambo 
DAUTZENBERG, G. 1978. Biblische Perspektiven zu Arbeit und Eigentum. (In Hertz, A., et al. Hrsg. Handbuch der Christlichen Ethik Band 2. Basel : Gutersloher Verlagshaus Gerd Mohn. p. 343-362.)

DEKKER, G. \& VEENHOF, J., red. 1986. Werken, zin of geen zin: Twaslf theologische visies op arbeid Baam : Ten Have.

DOUMA, J. 1984. Politieke verantwoordelikheid. Kampen : Van den Berg.

DOUMA, J. 1985. Vrede in de maatschappij: Een handleiding voor maatschappelijke vraagstukken. Kampen : Van den Berg.

DOUMA, J 1986. De Tien Geboden II. Kampen : Van den Berg.

DOUMA, J. 1992. Christelijke levensstijl. Kampen : Van den Berg.

DU RAND, J.A. 1992. Enkele Nuwe-Testamentiese perspektiewe met die oog op 'n Christelike etiese werkkultuur. Ned Geref Teologiese Tydskrif, 33(2): 157-164, Junie.

DU TOIT, B.A. 1994. Nuwe-Testamentiese perspektiewe oor die verdeling van rykdom Ned Geref Teologiese Tydskrif, 35(2):185-199, Junie.

DUVENAGE, B. 1957. Beroepsarbeid in die lig van die Gereformeerde etiek Potchefstroom : PUCHO.

DUVENAGE, B. 1972 Beroepsarbeid. (In De Klerk, W.J., et al. Roeping en werklikheid Potchefstroom : Potchefstroom Herald. p. 354-369.)

DUVENAGE, B. 1981. Roeping en wetenskap: Handleiding vir Wetenskapsleer Potchefstroom : Pro Rege.

DUVENAGE, B. 1983 Beroep en roeping Potchefstroom : PUCHO/IRS

ESTERHUYSE, W. 1991. Sake-etiek in die praktyk Pretoria : Van Schaik.

FAASEN, J. 1985. 'n Teologiese ondersoek na die grondlyne van 'n Christelike arbeidsetiek. US : Stellenbosch. (D.Th -proefskrif)

GEESINK,W. 1931. Gereformeerde ethiek 2. Kampen : Kok

GEREFORMEERDE KERKEN NEDERLAND (GKN). 1980. God met ons ... over de aard van het Schriftgezag. Leusden : Informatiedienst

HASELBARTH, H. 1989. Christian ethics in the African context. Nairobi : Uzima.

HEINTZMAN, P., VAN ANDEL, G.A. \& VISKER, T.L, ed. 1994 Christianity and Leisure: Issues in a pluralistic society. Sioux Center : Dordt College Press.

HENRY, C.F.H. 1980. Aspects of Christian social ethics. Grand Rapids : Baker.

HEYNS, J.A 1986. Teologiese Etiek 2/1. Pretoria : NG Kerkboekhandel

ILLANES, J.L. 1982. On the theology of work: Aspects of the teaching of the founder of Opus Dei Dublin : Scepter Books

KINOTI, G. 1994. Hope for Africa. Nairobi : Aisred

KOLFHAUS, D.W. 1949. Vom christlichen Leben nach Johannes Calvin Neukirchen : Kreis Moers.

KONIG, A. 1995. Versoening: Goedkoop? Duur? Verniet? Kaapstad : Lux Verbi

KONING, W 1986. Om de kwaliteit van werken in de toekomst. Radix, 12(1):56-83, Januarie. 
KRAAN, K.J. 1953. Een Christelijke confrontatie met Marx, Lenin en Stalin. Kampen : Kok.

KRITZINGER, J.J. 1994. Die missionère uitdaging van die arbeidslewe. Acta Theologica, 14(1):35-46, Junie.

KRUGER, S \& DE KLERK, G.J. 1995 Regstellende aksie: 'n etiese perspektief. Koers, 60(3):401-426, September

LEATT, J., KNEIFEL, T \& NÜRBERGER, K. 1986. Contending ideologies in South Africa Kaapstad : David Philip.

LOCHMANN, J.M. 1976. Ontmoeting met Marx: Wat Christenen en Marxisten verenigt en scheidt. Baarn : Bosch \& Keuning.

MANENSCHIJN, G 1987. Geldzucht de wortel van alle kwaad? Economie tussen moralisme en amoraliteit. Baarn : Ten Have

MANENSCHIJN, G. 1993. Mijn linkerhand is goed genoeg: Over medische ethiek, theologie, politiek en economie. Baarn : Ten Have.

MARSHALL, P. 1991. Calling, work and rest Potchefstroom : IRS/PUCHE

MAZAMISA, W 1994. Reparation and land (In Villa-Vilencio, C. \& De Guchy, J.W., ed. Doing ethics in context: South African perspectives. Kaapstad : David Philip p 210216.)

MOLTMANN, J Hrsg. 1979. Recht auf Arbeit, Sinn der Arbeit. München : Kaiser

MULDERS, P J 1991. Arbeid om te leven en arbeidsleven: Een theologisch-ethische verkenning van het fenomeen 'arbeid', in het bijzonder bij C.J. Dippel, A. Th. van Leeuwen, Hanna Arendt en FF Schumacher. 's-Gravenhage : Boekencentrum

NEUNER, J \& DUPUIS, J., ed 1983. The Christian faith in the doctrinal documents of the Catholic Church Glasgow : Collins

NOLAN, A 1991 A worker's theology (In Cochrane, JR. \& West, G.O., ed. The threefold cord: Theology, work and labour Hilton: Cluster. p. 160-168.)

NOORDEGRAAF, H 1987 Armen zullen nooit in het land ontbreken 's-Gravenhage Boekencentrum

NORVAL, E J.G. 1966. Arbeid: Prinsipiele ondersoek van arbeid met 'n kritiese toespitsing op enkele aktuele hoofmomente van die arbeidsetiek Potchefstroom : PUCHO. (Ph D Proefskrif.)

NORVAL, E.J.G. 1966a. Arbeid en die sedelike. Bulletin van die Suid-Afrikaanse Vereniging vir die beoordeling van ('hristelike Welenskap, 7:195-202, Desember

NÜRNBERGER, K. 1991 Prospects of employment: Scourge of unemployment (In Cochrane, JR. \& West, G O. The three-fold cord: Theology, work and labour. Hilton Cluster. p 28-65)

NYIRONGO, L 1994 Should a Christian embrace Socialism, Communism or Humanism? Potchefstroom : PUCHO

ORSMOND, E 1993 Die Nuwe Testament en arbeidsverhoudinge Ned Geref Teologiese Tydskrif, 24(2): 128-134, Junie

PETERSEN, R 1990 Die arbeider is sy loon werd. (In Venster op die sakewêreld. Perspektiewe op bedryfsetiek. Potchefstroom PUCHO/IRS p. 179-188.) 
PREISKER, H. 1936. Das Ethos der Arbeit in Neuen Testament. Göttingen : Gutersloh.

RAMOS, M. \& CASSIM, F. 1991. Nation-building and development strategy - the case for redistribution and growth. (In Vorster, W.S., ed. Building a new nation. Pretoria UNISA. p. 128-148.)

RENDTORFF, T. 1981. Ethik II. Stuttgart : Kohlhammer.

RICHARDSON, A 1963. The Biblical doctrine of work. London : SCM Press.

ROBERTSON, M., ed. 1991. Human rights for South Africans Oxford : Oxford University Press.

ROSCAM ABBING, P.J. 1978. Werk en werkloosheid: Een pastorale en ethische benadering Den Haag : Voorhoeve.

ROTHUIZEN, G.Th. 1980. Een bezige bij of de gereformeerde zede bestaat niet meer. Kampen : Kok.

RYKEN, L. 1987. Work and leisure in Christian perspective. Portland, Oregon : Multnomah Press.

SADIE, J. 1992. Herverdeling vind reeds dekades lank plaas. Beeld: 2, Junie 11

SLOVO, J. 1995. The right not to believe and the shared halves between socialism and religion. Journal of Theology for Southern Africa, 91:76-81, June.

SMIT, K 1992. Swart perspektiewe op affirmative action. Koers, 57(1):31-57, Maart

SOE, N.H 1965. Christliche Ethik: Ein Lehrbuch München : Kaiser.

STOKER, H.G. 1971-1973. Arbeid - wysgerig benader. Bulletin van die Suid-Afrikaanse Vereniging vir die bevordering van Christelike Wetenskap, 29:21-42, 30:50-60, 31:4360, 33:28-52, 36:5-27.

TAKI, N. 1991. Elements of a Theology of Work. (In Cochrane, J.R. \& West, G. O. The three-fold cord: Theology, work and labour. Hilton: Cluster. p. 28-65; p. 169-176.)

THIELICKE, H. 1965. Theologische Ethik 2/1. Tubingen : JCB Mohr (Paul Siebeck).

TRILLHAAS, W. 1970 Ethik. Berlin : Walter de Gruyter

VAN ANDEL, C.P. 1965. Ethiek van arbeid en rust. Nijkerk : Callenbach.

VAN DER MERWE, J.C 1994. Regstellende aksie: Prinsipièle riglyne. Potchefstroom IRS. (Studiestuk 313.)

VAN WYK, J.A. 1983 Opmerkings oor 'n Christelike etiek van die arbeid vir ons tyd. Ned Geref Teologiese Tydskrif, 24(1):72-86, Januarie.

VAN WYK, J.A. 1988 'n Christelike etiek van die arbeid Pretoria : N.G. Kerkboekhandel

VAN WYK, J.H. 1986. Gesindheid en gestalte Pretoria : N.G Kerkboekhandel

VAN WYK, J.H. 1991. Moraliteit en verantwoordelikheid: Opstelle oor politieke etiek. Potchefstroom : PUCHO

VAN WYK, J.H. 1993. Homo Dei: 'n Prinsipiele besinning oor enkele mensbeskouings, wasonder dié van Calvyn. Supplementum I In die Skriflig.

VAN WYK, J.H. 1995. Teologie van vergelding? Die Kerkblad 22-23, Jul 26.

VAN ZIJL, R. \& PUTTER, W. 1992. Geldsport: Ja of nee? (In Venster op sport: Christelike perspektiewe Potchefstroom PUCHO/IRS p 129-138) 
VELEMA, W.H 1974. Ethiek en pelgrimage: Over de bijbelse vreemdelingschap Amsterdam : Ton Bolland

VELEMA, W.H. 1980. Bijbelse uitgangspunte van 'n Calvinistische beroepsethiek Potchefstroom : IBC/PUCHO, Januarie.

VERKUYL, J. 1982. De kembegrippen van het Marxisme/Leninisme: Met een proeve tot evangelisch commentaar. Kampen : Kok.

VILLA-VILENCIO, C. 1992. A theology of reconstruction: Nation-building and human rights. Kaapstad : David Philip.

VOLF, M 1987. Arbeit und Charisma: $\mathrm{Zu}$ einer Theologie der Arbeit. Zeitschrift fur Evangelische Ethik, 31(4):411-433, Desember.

VOLF, M. 1988. Zukunft der Arbeit - Arbeit der Zukunf: Der Arbeitsbegriff bei Karl Marx und seine theologische Wertung. Munchen : Kaiser.

VOLF, M. 1991. Work in the spirit: Toward a theology of work. Oxford: Oxford University Press.

VOS, C.J A. 1986. Etiese besinning oor die stem van die werker en die Woord van God. Theologia Vialorum, 14(1):1-12, Junie

WALLACE, R.S. 1961. Calvin's doctrine of the Christian Life. Grand Rapids : Erdmans.

WESSLER, R. s.j. Sosiale etiek Otijmbingue SWA : Verenigde Lutherse Teologiese Seminarie

WITTENBERG, C. 1991. Old Testament perspectives on labour. (In Cochrane, JR \& West, GO. ed. The three-fold cord: Theology, work and labour. Hilton : Cluster p 28-65; p. 91-108)

WOLTERSTORFF, N 1984. Reason within the bounds of religion. Grand Rapids Eerdmans

WURTH, G.B 1951 Het Christelijk leven in de maatschappij. Kampen : Kok.

ZIMMERLI, W. 1979. Mensch und Arbeit im Alten Testament (In Moltmann, J Hrsg. Recht auf Arbeit, Sinn der Arbeit. Munchen : Kaiser. p. 40-58.) 
